\section{Pupa of Papilio Machaon}

WHILST working at the colour patterns of Insects in November $186 \%$, I very carefully dissected off a portion, about oneeighth of an inch square, of the hard integument from the side of a pupa of $P$. Machaon, near the anterior extremity. The portion of the interior thus displayed was filled with a clear colourless fluid, in which was floating a delicate membrane, to which were attached several tubes, trachea, formed by a spiral fibre. In the fluid were floating many roundish grains. Another pupa of the same brood was examined January 15, 1868, and another on April I 5. The floating grains were now evidently made up of ganglia of the spiral fibre of the trachea, and were connected with the tube by long pedicels of the same kind of fibre. On May 20 the tubes had enlarged to such an extent that they were almost contiguous, and were covered with minute granules, apparently incipient scales; in fact, a few small but well-formed scales appeared on one portion. The specimen examined in November was laid in cotton ; a perfect cicatrice was formed, and the butterfly in excellent condition appeared at the usual time.

Rainhill, December 23, I87 I HENRY H. HIGGINS

\section{Lunar Calendars}

IN reply to "Myops" in NATURE, No. III, p. I23, the English New Moon of the Jews is really the Month-Head (Caput mensis), formed from an artificial system. The true mean conjunction derived from the 19-year cycle is called the Molad or MoonBirth, and generally differs from the festival-day.

Said artificial system consists in combining $A Z, B Y, C X, \& c$, as follows :-

$$
\begin{aligned}
& \text { Ist Day of Pas:over has Black Fast ( } g \text { th } A b \text { ) on same week day. } \\
& \text { 2nd " " " xst of Pentecost. } \\
& 4^{\text {th }} \quad " \quad \text { " } \quad \text { " } \quad \text { xst of New Year (Tishri) } \quad \text { Labernacles-Rejoicing of Law. do } \\
& 5^{\text {th }} " \text { " "White Fast (Atonement Day). do. }
\end{aligned}
$$

This actual Jewish Calendar depends on the Moveable Feasts, Ist Passover never falling on Monday, Wednesday, or Friday. * 39, Howland Street, W., Dec. 15, 1871 S. M. DRACH

\section{Hints to Dredgers}

APPEALED to by name-spirits from the vasty deep-I have waited for my elders, also named, to answer Mr. Hennah's queries about dredging, and, failing to see anything more, I venture to trouble you with a few lines, the more so as I felt the want of advice when I was fitting out the Norna in 1870 . Details would be out of place here; I will only at present give a few hints. And first-to repeat Punch's advice to those about to marry-if about to buy a yacht, DoN'T! Begin by hiring one of the tonnage you require, the proper price being $I l$. 5 s. per ton per month, including the wages of skipper and crew, but rarely of cook or steward. After your first season buy by all means if you like.

If bound on a long cruise your craft should not be under 80 to roo tons. But for dredging in the Channel or round our coasts 25 tons and upwards are sufficient; but not on any account under that. A little boat of 25 tons makes up two good berths and two more possible ones, exclusive of the crew's sleeping quarters, and being decked stands a good chance in a gale of wind.

Beware the discomfort of a half-deck and a small boat, remembering that you may unavoidably have to face some nasty breezes which an ordinary yachtsman would run away from. You may, for iastance, be catught in a bay offering rich results, and have to thrash out of it.

Hire a man knowing the locality in which you desire to try your fortune.

Take a particular line, say the comparative life on the borders of fresh and salt water junctions, or at spots where the depth suddenly increases. No better locality, with a good pilot, could be picked out to begin with than the Channel Islands.

Especially note the submarine geology. Exactly fix the spots you dredge in by cross bearings. A small prismatic compass is invaluable, both afloat and ashore. Take carefully temperature, current, tidal observations, a multitude of soundings, and keep specimens of all. Fill a private log-loook with the most trivial and infantile details. You will afterwards laugh at much you have noted; but it is a great gain, and, unlike partridges, impressions are best fresh.

* For Mahommedan Calendar inquire of a Moslem, or such an authorit as Capt. R. J. Burton, the famous Hajji El-Iraki, and Consul to El-Sham.
This is not the occasion to go into matters of outit. One thing I must name, on no account let any man on board be without a life-belt for his own use.

Any intending dredger writing to me at this club will be cordially answered. A small squadron of yachts working together under a commodore of their own election would partition the labour, and produce a little emulation among the crews. Make a rendezvous every few days, and talk results over.

Marshall Hall

New University Club, St. James's Street, S. W., Jan. 6

\section{Anacharis Canadensis (A. Alsinastrum)}

I SHOULD esteem it as a favour if you would allow me to ask, through the medium of NATURE, if there be any published account of observations, confirmatory or otherwise, of $\mathrm{Mr}$. Wenham's notes on the free-cell formation which he has described as being carried on at the terminal growing point of Anacharis, quoted by Dr. Carpenter in "The Microscope and its Revelations," p. 405, et seq. (3rd ed.)

H. POCKLINGTON

\section{FIGHT BETWEEN A COBRA AND A MONGOOSE *}

THE snake was a large cobra $4 \mathrm{ft}$. $10 \frac{1}{2}$ in. in length, the most formidable cobra I have seen. He was turned into an enclosed outer room, or verandah, about $20 \mathrm{ft}$. by I $2 \mathrm{ft}$., and at once coiled himself up, with head erect, about ten or twelve inches from the ground, and began to hiss loudly. The mongoose was a small one of its kind, very tame and quiet, but exceedingly active.

When the mongoose was put into the rectangle, it seemed scarcely to notice the cobra; but the latter, on the contrary, appeared at once to recognise its enemy. It became excited, and no longer seemed to pay any attention to the bystanders, but kept constantly looking at the mongoose. The mongoose began to go round and round the enclosure, occasionally venturing up to the cobra, apparently quite unconcerned.

Some eggs being laid on the ground, it rolled them near the cobra, and began to suck them. Occasionally it left the eggs, and went up to the cobra, within an inch of its neck, as the latter reared up; but when the cobra struck out, the mongoose was away with extraordinary activity.

At length the mongoose began to bite the cobra's tail, and it looked as if the fight would commence in earnest. Neither, however, seemed anxious for close quarters, so the enclosure was narrowed.

The mongoose then began to give the cobra some very severe bites; but the cobra after some fencing forced the mongoose into a corner, ard struck it with full strength on the upper part of the hind leg. We were sorry for the mongoose, as but for the enclosure it would have escaped. It was clear that on open ground the cobra could not have bitten it at all ; while it was the policy of the mongoose to exhaust the cobra before making a close attack. The bite of the cobra evidently caused the mongoose great pain, for it repeatedly stretched out its leg, and shook it, as if painful, for some minutes. The cobra seemed exhausted by its efforts, and putting down its head, tried hard to escape, and kept itself in a corner. The mongoose then went up to it and drew it out, by snapping at its tail, and when it was out, began to bite its body, while the cobra kept turning round and round, striking desperately at the mongoose, but in vain.

When this had continued for some time, the mongoose came at length right in front of the cobra, and after some dodging and fencing, when the cobra was in the act of striking, or rather, ready to strike out, the mongoose, to the surprise of all, made a sudden spring at the cobra, and bit it in the inside of the upper jaw, about the fang, and instantly jumped back again. Blood flowed in large drops from the mouth of the cobra, and it seemed much

* The following interesting narrative has been obligingly forwarded to us by Prof. Andrews, of Queen's College, Belfast. 
weakened. It was easy now to see how the fight would end, as the mongoose became more eager for the struggle. It continued to bite the body of the cobra, going round it as before, and soon came again in front, and bit it a second time in the upper jaw, when more blood flowed. This continued for some time, until at last, the cobra being very weak, the mongoose caught its upper jaw firmly, and holding down its head, began to crunch it. The cobra, however, being a very strong one, often got up again, and tried feebly to strike the mongoose; but the latter now bit its head and body as it pleased; and when the cobra became motionless and dead, the mongoose left it, and ran to the jungle.

The natives said that the mongoose went to the jungle to eat some leaves to cure itself. We did not wish to prevent it, and we expected it would die, as it was severely bitten.

In the evening, some hours after the fight, it returned, apparently quite well, and is now as well as ever. It follows either that the bite of a cobra is not fatal to a mongoose, or that a mongoose manages somehow to cure itself. I am not disposed to put aside altogether what so many intelligent natives positively assert.

This fight shows at any rate how these active little animals manage to kill poisonous snakes. On open ground a snake cannot strike them, whereas they can bite the body and tail of a snake, and wear it out before coming to close quarters. This mongoose did not seem to fear the cobra at all ; whereas the cobra was evidently in great fear from the moment it saw the mongoose.

Ratnapura, Ceylon, April I I, I87 I

R. REID

\section{AUSTRALIAN PREPARATIONS FOR OBSERI- ING THE SOLAR ECLIPSE}

$\mathrm{THE}$ following letter has been received at the office of the English Government Eclipse Expedition, from the Government Astronomer at Melbourne :-

"Melbourne Observatory, Nov. 4, I871.

"My dear Sir,-The Eclipse instruments, copies of instructions, and your letter, reached me safely. Some of the instruments slightly damaged however, though not serious. About half the collodion bottles broken.

"The organisation of the Expedition is not yet quite complete; but a start, I think, is now certain. About $\mathrm{I}, 000 \mathrm{l}$. has been contributed by various Australian colonies:-Victoria, 450l.; New South Wales, 300l.; South Australia, I0ol. : Queensland, Iool.; and we expect to get $50 l$. from Tasmania. The cost of steamer, $\& c$., will be from 1,400l. to $1,500 l$. Twelve or fourteen amateurs have joined, paying $30 l$. each for passage. The voyage will occupy about four weeks, including a week or ten days at Cape Sidmouth. The country at Sidmouth is quite unknown, and inhabited only by Aboriginals, who, although not very warlike, are often exceedingly troublesome. Little is known of facilities for landing, \&cc., but as there are several coral islands in the vicinity, it is possible we may select some of them for observing stations, as they can easily be reached by laden boats. The whole of the coral sea inside the barrier reef is nearly always smooth water, so there cannot be much surf to contend with. The Expedition will have to start from here about the 2oth instant.

"Now, about our equipment:-First, we have Grubb's integrating spectroscope, which, by-the-bye, was considerably damaged; it had got adrift from its packing, and had evidently made sundry excursions of its own inside its case. Our instrument maker has set this right, and it is now in good working order, and $I$ tried it with the hydrogen spectrum yesterday, and it performs satisfactorily.

"Second; the large field analysing spectroscope came out all right, only one reflector of the kind indicated available, and that altazimuth mounting, Browning 8-inch.
We can hear of no others. We are busy making equa, torial mounting for this, but I am afraid we shall have no time to apply clock-work. One five-inch equatorial with its clock-work will be devoted to photographs, for this purpose the telescope will be dismounted and camera. substituted, as no good can be done with both.

"Third, Photography. We shall have to confine our. ielves to the operations with the camera as indicated in nstructions, and we are doing all we can to ensure good esults.

"Fourth. Polariscope work. - The two polarimeters ime all right. Prof. Wilson, of our University, has offered to take charge of polariscope observations ; his experience in experimenting on polarised light will ensure this part being thoroughly done if clouds permit.

"I think we thoroughly understand all the instruments and the instructions, and intend to take up such observa. tions which appear from the latter to be most desirable, and for which we have instrumental means.

"We have sets of Kirchhoff's and Angström's maps here, we shall have several hand spectroscopes, opera-glasses, \&c., provided for general observations.

"The little tube with the compound spectra of $\mathrm{Mg}, \mathrm{Ba}$, \&c., appears to require Leyden jar and coil and a strong current, even then I am doubtful if it can be used.

"We take up one or two field instruments to determine position, \&c.

"The observing party of Melbourne will number about nine, that from Sydney about six. We can at best only form two observing stations, and those not many miles removed from one another. Sydney observers, under Mr. Russell, will be engaged principally in photographs with refractor and spectrum work (analysing), and possibly we shall be able to arrange some polariscopes for them.

"I shall send you the earliest possible information of our success or otherwise on our return, which will be about Christmas.

"Our chances of fine weather are somewhat doubtful, as the cloudy N.W. monsoon generally sets in about the middle of December; it appears, however, that this seldom fairly sets in till after Christmas, and as the eclipse takes place on the $\mathrm{I} 2 \mathrm{th}$, we have some reason to hope for success.

"We are trying to get a recording spectroscope ready, but I am afraid there is scarcely time to finish it. The small telescope has a loose tube around it, covered with paper. The eye-piece and pointer slip across the field, and are made to do so by a long lever, moved by a pricking frame.

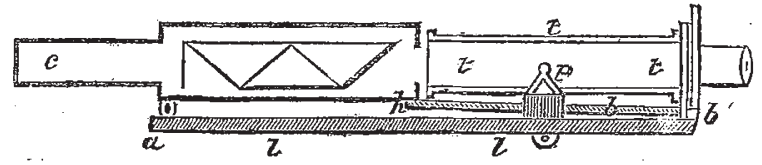

tt $t$ is a loose tube forming recording barrel, $b b$ is attached to eye-piece by flat spring, $l l$ long lever pointed at $a$, $h$ slide bar parallel to telescope, $p$ pricker frame which slides along $b b$ crossing eye-piece and pointer to traverse field (the lever and slide bar are drawn too parallel, they should be more inclined to one another). By moving $p$ up and down the slide bar the pointer is made to coincide with a line, and the pricker $p$ is pressed-after pricking one set the loose tube is slightly revolved, and a second set obtained. It is nearly complete, but has not been tried yet. I hope you will have good success in India.

"At Cape Sidmouth we shall have $3 \mathrm{~m}$. 34s. totality, the sun at an altitude of about $45^{\circ}$, a more convenient position than I thought before the data were computed. Like you, we are working almost night and day to get ready, for it was only a fortnight ago I had authority from Government to organise a party and prepare instruments. Again wishing you the best success,

\section{"J. NORMAN LOCKYER, ESQ."}

